Acta Universitatis Nicolai Copernici • Pedagogika XXXV/1/2018

Nauki Humanistyczno-Społeczne • Zeszyt 445

DOI: http://dx.doi.org/10.12775/AUNC_PED.2018.006

\author{
Jarosław Korczak \\ Academy of Special Education in Warsaw \\ ORCID: 0000-0002-9851-424X
}

\title{
The EDUCATIONAL FORTUNES \\ of the Three Waves of Polish emigration \\ to Australia in its historical \\ AND CULTURAL CONTEXT
}

\begin{abstract}
The problem focused upon in this article is approached by presenting the characteristics of three waves of Polish emigration to Australia, with particular emphasis on the question of education. The factors, the presence of which influenced the course of emigration, have been discussed in detail. In particular, the motives of migration and the socio-political background and the socio-economic underpinnings accompanying the cultural adaptation of the Polish diaspora in Australia are explored within a specific time period. By making a historic analysis of Polish emigration to Australia, one can discern more waves. However, the most important waves are those related to historic events in Poland such as World War II, the activity of the Solidarity opposition and the transformation changes after the year 1989.

The turning point was the year 1947, in which the presence of Poland in Australia became noticeable. With the passing of time, and the emergence of some significant political events in Poland, the number of emigrants in Australia has risen. However, each of the waves have differed, in many aspects, from earlier ones which, as the author proves, has had a significant effect on
\end{abstract}


the educational fortunes of persons belonging to a particular wave of emigration.

Ke y w ord s: education in Australia, Polish diaspora in Australia, educational fate.

Trzy fale emigracji Polaków do AustraliI - trzy ścieżKi edukacyjne

\section{Streszczenie}

Problematyka skupia się dokonaniu charakterystyki trzech fal polskiej emigracji do Australii ze szczególnym uwzględnieniem wątku edukacyjnego. Dokonując analizy historycznej polskiej emigracji w Australii można by ich wyróżnić więcej. Najważniejsze są jednak powiązane z takimi wydarzeniami historycznymi w Polsce jak: druga wojna światowa, działalność opozycji solidarnościowej oraz przemiany ustrojowe po 1989 roku. Punktem zwrotnym był 1947 rok, w którym obecność Polaków na antypodach stała się zauważalna. W miarę upływu czasu i zaistnieniu ważnych politycznie wydarzeń w Polsce ilość emigrantów w Australii rosła. Każda z fal różniła się jednak w wielu aspektach od poprzedniej, co miało znaczący wpływ również na losy edukacyjne emigrantów.

Słow a kluczowe: edukacja w Australii, Polonia australijska, losy edukacyjne.

\section{Preface}

The making of description of the waves of emigration, inclusive of $\perp$ educational fortunes of emigrants, requires broader perspective, taking into consideration of historic, social and political aspects. The waves of emigration from Poland to Australia was an issue covered by several authors (Ewa Lipińska, Jan Lencnerowicz, Jerzy Jarosław Smolicz, Krzysztof Markowski, Katarzyna Kwapisz, Piotr Listkiewicz, Krystyna Włodarczak, Elizabeth Drozd). Information on this issue appeared also on websites of Polish diaspora organisations in Australia (cf Monika Kowalczyk - australink.pl, Przemek - antypody.info, Mar- 
ysia Thiele ewpl.com.au). The number of emigration waves is determined differently, e.g. Monika Kowalczyk ${ }^{1}$ mentions five of them all together, and Marysia Thiele ${ }^{2}$ cites three, according to other criteria. Generally speaking, the vast majority of authors speaks of three criteria of indicating waves of emigration: a) a number of Poles have arrived in Australia, b) circumstances of their arrival, c) reasons for selecting Australia as their destination. Regarding the waves described, the educational context is considered rather scantily.

The three waves of emigration to Australia are the following taking into account the above criteria: World War II (first wave), the solidarity opposition movement (second wave), and free Poland after 1989 (third wave). Each of these emigration waves differ from one another.

- by number of arrived Polish people;

- by distinct perception of Poland as country of their descent;

- by circumstances and conditions accompanying arrival to Australia;

- by motives of selecting new country;

- educational experiences of their representatives.

These differences have influenced the progress of these people's subsequent fortunes in connection with education and professional development.

In order to convey in a comprehensive manner the fortunes of education of the emigrants belonging to specific waves, one should characterise them as precisely as possible, while depicting the circumstances in which the emigrants came to function. However, in order to describe the above-mentioned three waves, one should attempt to depict, at least briefly, the earlier history of Polish presence in Australia.

1 M. Kowalczyk, Polska emigracja do Australii - poczatki i fala po II Wojnie Światowej, 2014a, http://australink.pl/polska-emigracja-do-australii-poczatki-ifala-po-ii-wojnie-swiatowej/.

2 M. Thiele, Trzy fale polskiej emigracji do Australii Południowej, http://ewpl. com.au/trzy-fale-polskiej-emigracji-do-australii-poludniowej/. 


\section{Poles in Australia}

The history of Polish settlement in Australia goes back over 200 years. However, the arrival of first Pole to Australia was not out of his own volition. He was convicted by the British government for theft and arrived into this new land, as a convict. Most probably, his name was Józef Potowski ${ }^{3}$, while other sources state his name to be Jan Potaski ${ }^{4}$, although there is no certainty as regards the spelling of his surname (Patoskey, Potaskee, Potasky, Potocki etc.). There is also some ambiguity concerning his date of birth. After coming to Australia in 1803, initially, he settled in the abandoned settlement of Sorrento by Sullivan Bay in Port Phillip Bay and a year later he moved over to the Hobart settlement on the island of Van Diemen's (in 1856 its name was changed to Tasmania) where he lived and worked as a farmer ${ }^{5}$. He died on the $31^{\text {st }} \mathrm{Au}-$ gust 1824 at the age of 50 or 62 years ${ }^{6}$.

The first group of Polish settlers, which derived from Wielkopolska, settled in Australia in 1856 (having arrived from Dąbrówka Wielkopolska in 1848)7. This community, counting a mere 146 persons, set as its goal the setting of a Catholic settlement in that part of the world ${ }^{8}$. They settled at Polish Hill River close to the Sevenhill locality, situated in Clare Valley in Southern Australia ${ }^{9}$. A great contribution in that en-

3 M. Kowalczyk, Polska emigracja do Australii - początki i fala po II Wojnie Światowej, 2014a, http://australink.pl/polska-emigracja-do-australii-poczatki-ifala-po-ii-wojnie-swiatowej/.

4 D. Cahill, John Potaski, Australia's First Polish Settler: A Problematic Beginning, In: Polonia in Australia: challenges and possibilities in the new millennium, eds. E. Drozd, D.A. Cahill, Victoria 2004, p. 1.

5 Ibid., p. 1.

6 Ibid., p. 3.

7 M. Kowalczyk, Polska emigracja do Australii - początki i fala po II Wojnie Światowej, 2014a, http://australink.pl/polska-emigracja-do-australii-poczatki-ifala-po-ii-wojnie-swiatowej/.

8 Ibid.

9 D. Gromann, Polonia w Australii, „Biuletyn Migracyjny” dodatek Specjalny, 2012, no. 33, p. 1. 
deavour was ascribed to father Leo Rogalski ${ }^{10}$, thanks to the efforts of whom, a school was built, in which later on he used to give classes ${ }^{11}$. In the 20s of the XX c. the school got devastated. Only half a year later, new emigrants rebuilt the church, which served the needs of the first Polish diaspora. Since 1988, it housed the museum of the Polish Migration (Polish Hill River Church Museum), constituting a significant venue on the Polish diaspora's map of Australia ${ }^{12}$.

The population census (CENSUS) from 1921 contains the first official data concerning the population of the people of Polish origin inhabiting Australia ${ }^{13}$. The number was estimated at 1780 persons $^{14}$. Over a half of this group arrived prior to the setting up in 1901 of the Commonwealth of Australia ${ }^{15}$. It is estimated that over $80 \%$ of the people coming over from Poland during the 20s of the XX c. were of Jewish religion ${ }^{16}$. When the emigration programme was recommenced in 1947, the Polish community in Australia counted just 6573 persons, out of which almost 4000 persons - mainly Jews - inhabited Melbourne ${ }^{17}$. During the following seven years, the number of the settlers of Polish descent increased by approx. $50000^{18}$.

10 J. Jupp, The Polish Impact on Australian Society, In: Polonia in Australia: challenges and possibilities in the new millennium, eds. E. Drozd, D.A. Cahill, Victoria 2004, p. 9.

11 L. Paszkowski, Polacy $w$ Australii i Oceanii 1790-1940, Toruń-Melborn 2008, p. 33.

12 D. Gromann, Polonia w Australii, „Biuletyn Migracyjny” dodatek Specjalny, 2012, no. 33, p. 1.

13 S. Markowski, K. Kwapisz Williams, Australian Polonia: A Diaspora on the Wane?, „Central and Eastern European Migration Review”, 2013, vol. 2, no. 1, p. 18.

14 S. Markowski, Citizenship and integration: A snapshot of the Polish migrant community in Australia, „Humanities Research”, 2009, vol. XV, no. 1, p. 81.

15 R.M. Harris, J.J. Smolicz, Australijczycy polskiego pochodzenia: Studium adaptacji i asymilacji młodego pokolenia, Wrocław 1984, p. 48.

16 C.A. Price, Jewish Settlers in Australia 1788-1961, „Australian Jewish Historical Society Journal and Proceedings", 1964, no. 5(8), p. 361.

17 J. Jupp, The Polish Impact on Australian Society, In: Polonia in Australia: challenges and possibilities in the new millennium, eds. E. Drozd, D.A. Cahill, Victoria 2004, p. 10.

18 Ibid., p. 10. 


\section{The first wave}

The end of World War II saw the start of influx of emigrants to Australia from several European countries. Apart from Poles, they also came from Spain, Italy, Greece and Yugoslavia, as well as many Jews ${ }^{19}$. From 1947-1954, the number of Australians born in Poland grew to 56,59420. As recounts Lencznarowicz (1994), after taking into account children born to Polish families already living outside of Poland (mainly in Germany) and excluding German women, the wives of Polish emigrants and Ukrainians and Russians faking Polish descent out of fear of being deported back to the USSR, the entirety of Polish emigration to Australia in the years 1947-1954 is estimated at around 65 thousand people ${ }^{21}$ ". Even though the newcomers from Poland had already lived in Australia for many years, only the arrival of the "first wave" came to be the foundation for developing Polish diaspora down under ${ }^{22}$ whereas the subsequent waves only served to complement and differentiate $i^{23}$.

The first group of Polish emigrants to number several hundred from that time were the soldiers or combatants of the former Independent Brigade of Karpaty Riflemen fighting in 1941 alongside the Australians at the battle of Tobruk ${ }^{24}$. Overall, according to Egon F. Kunz, under the programme of resettling Polish combatants to Australia 1,457 persons

19 P. Listkiewicz, Australia - przeklęta ziemia obiecana - wielokulturowość we wstecznym lusterku, http://studiozaprog1.blogspot.com/2011/05/piotr-listkiewicz-australia-przekleta_3863.html.

20 S. Markowski, Citizenship and integration: A snapshot of the Polish migrant community in Australia, „Humanities Research”, 2009, vol. XV, no. 1, p. 81.

21 J. Lencznarowicz, Prasa i społeczność polska w Australii: 1928-1980, Kraków 1994, p. 31.

22 J. Jupp, The Polish Impact on Australian Society, In: Polonia in Australia: challenges and possibilities in the new millennium, eds. E. Drozd, D.A. Cahill, Victoria 2004, p. 9.

23 J. Lencznarowicz, Prasa i społeczność polska w Australii: 1928-1980, Kraków 1994, p. 31.

24 Ibid., p. 24. 
arrived $^{25}$. The number of 4,000, which is occasionally stated in this respect, seems also to cover the soldiers of the Polish 1939 defence war against the Germans, the AK (Polish WWII resistance army) and the soldiers of the Warsaw 1994 uprising arrived in Australia ${ }^{26}$.

The second biggest group of emigrants of the "first wave" 27 constituted the so-called displaced persons, i.e. people who, due to the war, found themselves beyond own country's borders and wanted to return home or else find for themselves a new country to live in, who couldn't manage to achieve these goals without external help. The displaced persons were people who were transported for forced labour to the German III Reich and freed from concentration camps as war prisoners, Jews from the death camps, people earlier deported, detained, and those who in the first days of the war were seeking asylum in neutral countries, so as to fight in the Polish Army in the West later on ${ }^{28}$.

Overall, in Australia in the years 1948-1953 under the programme of displaced persons repatriation, a group of Poles arrived counting several dozen thousand people, thus becoming the biggest national group amongst the 170 thousand refugees representing other nationalities. The Poles used to arrive mainly from the Western parts of Germany and Austria, almost 1200 people - in general women and children came by sea from Eastern Africa ${ }^{29}$, from the camps established by the Red Cross in British colonies, for refugees from Siberia ${ }^{30}$. These were

25 E.F. Kunz, Post-war non-British immigration, In: The Australian people: An encyclopedia of the nation, its people and their origins, eds. J. Jupp Sydney 1988, p. 82.

26 J. Lencznarowicz, Prasa i społeczność polska $w$ Australii: 1928-1980, Kraków 1994, p. 26.

27 S. Markowski, K. Kwapisz Williams, Australian Polonia: A Diaspora on the Wane?, „Central and Eastern European Migration Review”, 2013, vol. 2, no. 1, p. 18.

28 M. Kowalczyk, Polska emigracja do Australii - początki i fala po II Wojnie Światowej, 2014a, http://australink.pl/polska-emigracja-do-australii-poczatki-ifala-po-ii-wojnie-swiatowej/.

29 J. Lencznarowicz, Prasa i społeczność polska $w$ Australii: 1928-1980, Kraków 1994, p. 28-29.

30 M. Thiele, Trzy fale polskiej emigracji do Australii Południowej, http://ewpl. com.au/trzy-fale-polskiej-emigracji-do-australii-poludniowej/. 
mainly men in the 25-39 age group, who were coined as "unqualified labour force, in majority, coming from rural areas" out of which, $60 \%$ had no qualifications whatsoever ${ }^{31}$.

Roger Harris and Jerzy Smolicz perceive as the reason for such representation of Polish emigrants the process of double selection of people arriving in Australia ${ }^{32}$. The first selection involved the persons who survived the war in the West and did not constitute a proportionate representation of the pre-war Polish society. The campaign of transporting people away from Poland and, in particular, the intellectuals, teachers, and freelancers, as well as deaths of many representatives of intelligentsia during the Warsaw Uprising meant that some layers of the Polish society were - among the people, who survived the war clearly underrepresented. The second selection took place at time of deciding as to a venue of settlement. Since it was generally known, that this particular country needs most of all workers, people with higher qualifications, and also with greater odds of emigrating to other countries, used to opt for other destinations of emigration, especially England, the United States and Canada ${ }^{33}$.

As Egon F. Kunz stresses ${ }^{34}$, the recruitment of Poles commencing in 1948 was carried out according to a "more demanding procedure" than was the case with respect to other nationalities earlier accepted. Only single people and childless married couples were admitted ready for instant employment, whereas the Poles laden with their families used to wait until February $1949^{35}$. The cost of their immigration was covered by the Australian government; however, in exchange they had to sign a contract under which they were obliged to work for two years in ac-

31 R.M. Harris, J.J. Smolicz, Australijczycy polskiego pochodzenia: Studium adaptacji i asymilacji młodego pokolenia, Wrocław 1984, p. 60.

32 M. Kowalczyk, Polska emigracja do Australii - początki i fala po II Wojnie Światowej, 2014a, http://australink.pl/polska-emigracja-do-australii-poczatki-ifala-po-ii-wojnie-swiatowej/.

33 Ibid.

34 E.F. Kunz, Post-war non-British immigration, In: The Australian people: An encyclopedia of the nation, its people and their origins, eds. J. Jupp Sydney 1988, p. 43.

35 Ibid., p. 43. 
cordance with Australian government places, with the same financial terms as those of the Australian workers. In the case of a failure to sign contract or failure to fulfil it, they were to be deported ${ }^{36},{ }^{37}$. Usually, they were sent inland in Australia, where they used to live and work in isolation from the Australia society, in hot climate and harsh conditions $^{38}$.

On the turn of the 1950s and 60s, thanks to temporary improvement of political situation and changes in visa provisions, the Poles had a chance once again to cross the borders of this foreign land. Many of the Poles already living in Australia took this opportunity to repatriate their families. It is estimated that the years 1956-1966 saw the coming to Australia of another group of almost 15,000 emigrants from Poland $^{39}$, out of which many found themselves under the family unification programmes ${ }^{40}$. Newcomers with their experience and lifestyle, and frequently education, used to differentiate themselves from their relatives and friends already staying in Australia ${ }^{41}$.

As Charles A. Price estimates, in the years 1947-1981 there were almost 100000 people born in Poland, who settled in Australia. The Poles, just like the comers from other countries of Central and Eastern Europe, rarely decided to re-emigrate ${ }^{42}$.

36 J. Lencznarowicz, Prasa i społeczność polska w Australii: 1928-1980, Kraków 1994, p. 26.

37 M. Kowalczyk, Polska emigracja do Australii - początki i fala po II Wojnie Światowej, 2014a, http://australink.pl/polska-emigracja-do-australii-poczatki-ifala-po-ii-wojnie-swiatowej/.

38 J. Lencznarowicz, Prasa i społeczność polska w Australii: 1928-1980, Kraków 1994, p. 27.

39 S. Markowski, K. Kwapisz Williams, Australian Polonia: A Diaspora on the Wane?, „Central and Eastern European Migration Review”, 2013, vol. 2, no. 1, p. 19.

40 K. Włodarczak, Proces adaptacji współczesnych emigrantów polskich do życia $w$ Australii, „CMR Working Papers” 2005, no 3/61, p. 16.

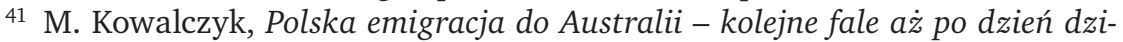
siejszy, 2014b, http://australink.pl/polska-emigracja-do-australii-kolejne-fale-azpo-dzien-dzisiejszy/.

42 J. Lencznarowicz, Prasa i społeczność polska w Australii: 1928-1980, Kraków 1994, p. 31-32. 
In opposition to many other nationality groups, the Polish group did not constitute a large percentage of persons having high qualifications or well-founded social status. Almost 15,000 displaced Polish people were children born in Germany or Austria. As many as 85\% of men between 19-60 years of age had just elementary education, while only $2 \%$ had third level education. Approximately $60 \%$ of entire group were peasants or unqualified workers, and $25 \%$ were qualified workers ${ }^{43}$.

However, it should be noted that the contemporary information amassed by the International Refugees Organisation may be incomplete and hence its reliability has also posed certain questions ${ }^{44}$. Among others, due to the fact that a certain group of potential emigrants accepted the strategy of providing only such information about them, which in their opinion were convenient for ensuring their comfortable arrival in Australia. This occurred, in particular, in the context of bearing the costs of journey by the Australian government. The newcomers, according to the agreement, agreed to work in indicated locations, as "workers" (construction, forestry and farming), "factory workers", or "staff" (in hospitals and hotels). In doing so, they were engaged in work in accordance with the declared qualifications, irrespective of the real ones ${ }^{45}$.

The Australian government used to treat all comers equally. Origin, social classes or qualifications were meaningless at the time ${ }^{46}$. In particular, the higher qualifications attained in Europe were ignored. Hence, men were classified as labourers, and women, as domestic aid. If someone changed the type of performed work out of his or her own volition, they faced with deportation ${ }^{47}$.

43 Ibid., p. 28-29.

44 R.M. Harris, J.J. Smolicz, Australijczycy polskiego pochodzenia: Studium adaptacji i asymilacji młodego pokolenia, Wrocław 1984, p. 55-56.

45 S. Markowski, K. Kwapisz Williams, Australian Polonia: A Diaspora on the Wane?, „Central and Eastern European Migration Review”, 2013, vol. 2, no. 1, p. 19.

46 M. Kowalczyk, Polska emigracja do Australii - poczactki i fala po II Wojnie Światowej, 2014a, http://australink.pl/polska-emigracja-do-australii-poczatki-ifala-po-ii-wojnie-swiatowej/.

47 J. Lencznarowicz, Prasa i społeczność polska w Australii: 1928-1980, Kraków 1994, p. 29-30. 
The majority of comers, the first couple of months or years used to spend at camps (hostels), places of employment (e.g. hospitals or private homes) or at pensions. Only some of them had a chance to start living promptly on their own in hired residences or make-shift houses (garages), on acquired plots of land. Married couples were often separated. Men were sent to work inland in Australia, hence due to long distance, they visited their families just every few weeks ${ }^{48}$. From the refugee camps, organised far away from larger municipalities, they were transported away to reclaimed bush, hired as farm workers and worked to harvest sugar cane. Locations were chosen in such a way, so as to satisfy the demand for labour (mainly unqualified) in such spheres of occupation and such regions, which the native Australians avoided.

Hence, competition for work places and places of living between newcomers and the accepting community were kept at bay ${ }^{49}$. As Ewa Lipińska writes, the conditions of living (especially at first) were more than modest. Newcomers were affected by hot weather, hard, low paid labour, lack of decent places of living and territorial dispersion ${ }^{50}$. Women, who started their work as domestic aid, often used to remain in that occupation until their retirement age.

Having completed the two years of forced labour, men often took jobs in construction and maintenance of railway, water system, roads, construction of rolling stock, in construction industry, forestry, farming or food processing industry ${ }^{51}$. As Piotr Listkiewicz writes, in Brisbane, the 'Polish' factory was cement factory, which was initially built by the Poles, and then worked by them; it was also a place around which they built their houses, and so they are living until today. Their knowledge of English language is not great even to this day, even though Polish is

48 Ibid., p. 29-30.

49 M. Kowalczyk, Polska emigracja do Australii - początki i fala po II Wojnie Światowej, 2014a, http://australink.pl/polska-emigracja-do-australii-poczatki-i-fala-poii-wojnie-swiatowej/.

50 E. Lipińska, Polskość w Australii: o dwujęzyczności, edukacji i problemach adaptacyjnych Polonii na antypodach, Kraków 2013, p. 58.

51 M. Kowalczyk, Polska emigracja do Australii - początki i fala po II Wojnie Światowej, 2014a, http://australink.pl/polska-emigracja-do-australii-poczatki-i-fala-poii-wojnie-swiatowej/. 
almost forgotten ${ }^{52 "}$. In contrast, the women used to work later as domestic aid in private homes and as workers in food processing industry, textile and clothing industries ${ }^{53}$.

The above characterisation is evidenced by the results of the research conducted by Jerzy Smolicz amongst the children of the first wave of emigrants. In Poland, a few "worked as freelancers, approximately a fourth of them were office clerks or qualified workers, and similar number worked as unqualified workers, mainly in agriculture. This structure of professions was changed in Australia. Only a half of the most qualified persons managed to attain similar status to that held prior to their departure for Australia, and only a few others reached this high status already in Australia. The percentage of the office and labour professions not requiring qualifications went on rising. However, the number of qualified persons was maintained at a similar level, since it was also formed by a large group of persons, who obtained their profession already in Australia. Only a few were able to apply the obtained in Poland qualifications without bigger changes"54.

For years, comers representing the first wave used to living and working among other "New Australians", frequently far away from the central urban areas. While trying to break away from the isolation from the Australian society, they often encountered the barrier of language, customs or aversion from the indigenous people ${ }^{55}$. The professions and places of their performance did not do much good towards full assimilation, both, when it came to the language issue or the issue of culture. The end result was that the Poles frequently looked for help within their own ethnic group. Due to this, the separated group of Pol-

52 P. Listkiewicz, Australia - przeklęta ziemia obiecana - wielokulturowość we wstecznym lusterku, http://studiozaprog1.blogspot.com/2011/05/piotr-listkiewicz-australia-przekleta_3863.html.

53 M. Kowalczyk, Polsk̄a emigracja do Australii - początki i fala po II Wojnie Światowej, 2014a, http://australink.pl/polska-emigracja-do-australii-poczatki-i-fala-poii-wojnie-swiatowej/.

54 J.J. Smolicz, M.J Secombe, Zostać Australijczykiem? Polski dom, australijska szkoła, Warszawa 1990, p. 58.

55 J. Lencznarowicz, Prasa i społeczność polska w Australii: 1928-1980, Kraków 1994, p. 29-30. 
ish comers has turned into an organised community, with their own societies, clubs, schools, press folk groups and churches ${ }^{56},{ }^{57}$.

As Ewa Lipińska notes, the first wave consisted mainly of two groups which, in spite of finding themselves in a similar situation, differed substantially from one another. The first one was made up of former soldiers and officers of the general Anders' army and the Battle of Britain campaigners, who came over from Great Britain. The majority of them had a good command of the English language and the officers completed a higher level of education which facilitated them in taking up fair work later. The second group was constituted mainly by workers transported to Germany beforehand for forced labour, often with poor education (four classes of elementary school), who did not know the language and had no real qualifications in specific professions ${ }^{58}$.

As Piotr Listkiewicz recounts, this situation generated certain divisions within the wave. The members of the first group perceived themselves - and still do today - as belonging to a class much higher than the second one ${ }^{59}$. Moreover, as Jan Lencznarowicz writes, "Experience of German occupation, many years of wandering and life at prisoners' camp affected the mentality of the displaced persons, and at times it led to alcoholism, disturbances and nervous diseases. Not all of the refugees got rid of the common for the European refugees' apathy, as there was still sensed among them the expectation of care and assistance, a certain kind of "learnt helplessness"60.

In spite of these divisions, it can most certainly be said that the thing cementing the group together was national culture, anti-communist

56 K. Włodarczak, Proces adaptacji współczesnych emigrantów polskich do życia w Australii, „CMR Working Papers” 2005, no. 3/61, p. 15.

57 J. Lencznarowicz, Diaspora Polska w Australii, in: Polska Diaspora, eds. A. Walaszek, Kraków 2001, p. 401.

58 E. Lipińska, Polskość w Australii: o dwujęzyczności, edukacji i problemach adaptacyjnych Polonii na antypodach, Kraków 2013, p. 58.

59 P. Listkiewicz, Australia - przeklęta ziemia obiecana - wielokulturowość we wstecznym lusterku, http://studiozaprog1.blogspot.com/2011/05/piotr-listkiewicz-australia-przekleta_3863.html.

60 J. Lencznarowicz, Prasa i społeczność polska w Australii: 1928-1980, Kraków 1994, p. 31. 
ideology and attitude, as well as political activism in support of Poland's regaining of independence (inclusive of identification with Polish government in exile) ${ }^{61}$. This group was enough independent and resilient, so that throughout the years it managed to preserve own language - defined by Smolicz ${ }^{62}$ as "core values" of the Catholic religion and tradition. There also set in place some strong ethnic bonding and mechanisms of support within the community.

\section{Second wave}

The so-called second wave was composed of Polish emigrants, who decided to arrive in Australia in the 1980s. Due to the various complications in connection with arrival, some of them reached Australia only in the early 90s, although they are counted as the second wave ${ }^{63}$. Already in 1980, there were 2,400 newcomers and, until 1984, almost 16 thousand of Poles settled in Australia ${ }^{64}$. Markowski states that in general in the years 1980-1991 there came and settled in Australia over 25000 Poles $^{65}$. The newcomers representing the second wave were mainly young people, inhabitants of urban areas, frequently with higher education and specialist qualifications, often commanding good English skills and hence, greater expectations in the context of their conditions of settling in Australia ${ }^{66}$.

61 J. Lencznarowicz, Diaspora Polska w Australii, in. Polska Diaspora, eds. A. Walaszek, Kraków 2001, p. 405-406.

62 J.J. Smolicz, Core values and cultural identity, „Ethnic and Racial Studies”, 1981, no. 4(1), p. 75-90.

63 S. Markowski, Citizenship and integration: A snapshot of the Polish migrant community in Australia, „Humanities Research”, 2009, vol. XV, no. 1, p. 81.

64 A. Jamrozik, Recent Polish Immigration, In: The Australian People: An Encyclopedia of the Nation, it's People and their Origins, eds. J. Jupp, Australia 2001, p. 627-628.

65 S. Markowski, Citizenship and integration: A snapshot of the Polish migrant community in Australia, „Humanities Research”, 2009, vol. XV, no. 1, p. 75-99.

66 E. Drozd, They have come a long way: The settlement of the 1980s wave of Polish immigrants in Melbourne. Melbourne 2001. 
This wave was called "solidarity emigration" $67,68,69$, "post-solidarity emigration"70,71. The arrival of these people was linked to their activity in the solidarity opposition. Many people linked to it had to flee to other countries in order to avoid oppression in the territory of Poland. Obviously, apart from political or ideological motives, "harsh political situation, meaning lack of freedom and significant restraint of civic freedoms"72, played their part, as Ewa Lipińska points, alongside other motives such as the curiosity about the world and typical economic reasons.

In most cases, these people counted on the raising of their up-todate living standard. Many of the representatives of the second wave somewhat exaggerated self-personification in the face of regime persecution ascribing to themselves the role of refugees ${ }^{73}$. Referring to the portal antypody.info, Przemek states that "some of them really got their one-way ticket passport from the communist authorities. Whereas others, simply took advantage of the opportunity to start a new life in a better world"74. However, the majority of them were characterised "frequently by a sense of frustration, underestimation, tiredness and discouragement to any activity - not just political"75.

67 P. Listkiewicz, Australia - przeklęta ziemia obiecana - wielokulturowość we wstecznym lusterku, http://studiozaprog1.blogspot.com/2011/05/piotr-listkiewicz-australia-przekleta_3863.html.

68 M. Thiele, Trzy fale polskiej emigracji do Australii Południowej, http://ewpl. com.au/trzy-fale-polskiej-emigracji-do-australii-poludniowej/.

69 J. Lencznarowicz, Prasa i społeczność polska w Australii: 1928-1980, Kraków 1994.

70 K. Knyżewski, O specyfice współczesnej polskiej emigracji, In: Przemiany społeczne kwestie narodowościowe i polonijne, eds. A. Chodubski, Toruń 1994.

71 E. Lipińska, Polskość w Australii: o dwujęzyczności, edukacji i problemach adaptacyjnych Polonii na antypodach, Kraków 2013, p. 61.

72 M. Sprengel, Emigracja polska w Australii w latach 1980-2000, Toruń 2004, p. 62

73 E. Lipińska, Polskość w Australii: o dwujęzyczności, edukacji i problemach adaptacyjnych Polonii na antypodach, Kraków 2013, p. 61.

74 Przemek, Krótka historia polskiej emigracji do Australii, http://antypody. info/2009/05/krotka-historia-polskiej-emigracji-do-australii/.

75 E. Lipińska, Polskość w Australii: o dwujęzyczności, edukacji i problemach adaptacyjnych Polonii na antypodach, Kraków 2013, p. 60-61. 
Moreover, the implementation of the martial law in Poland in 1981 meant, for many people, staying abroad separation from Poland for $\operatorname{good}^{76}$. At that time, Australia became for them an attractive place to emigrate to, especially when they could avail of the special programmes of aid for the emigrants, while martial law facilitated those staying in Australia with the acquisition of the right of permanent residence as political refugees ${ }^{77}$. Before crossing the Australian border, many of them spent months, even years, staying in intermediary camps in Western Europe ${ }^{78}$, and mainly in German Federal Republic of Germany, Austria and Italy.

In the opinion of Piotr Listkiewicz, the group of emigrants of the second wave was ideologically differentiated. In spite of being born and educated in the communist Polish People's Republic, not all felt themselves to be communists or socialists: "Even though we were indoctrinated all the time, and some belonged to the communist party, every single one of us had his or her own opinion based on everyday experience of reality. In the end, the majority of us fled Poland, because for some reasons we could not live in our country. However, for the Polish diaspora (i.e. the first wave) they were all the same, strangers and dangerous"79.

Irrespective of the motives for arrival, this was in fact due to the initiative of the wave coming over in that very time, that several societies and groups of support, as well as numerous campaigns and demonstrations were organised for the purpose of providing more widespread information to the Australian society of the nature and goals of the "Solidarity" movement and of the support for its struggle with the Polish communist government. A large number of native Australians ex-

76 M. Sprengel, Emigracja polska w Australii w latach 1980-2000, Toruń 2004, p. 65.

77 J. Lencznarowicz, Prasa i społeczność polska w Australii: 1928-1980, Kraków 1994, p. 31-32.

78 M. Thiele, Trzy fale polskiej emigracji do Australii Południowej, http://ewpl. com.au/trzy-fale-polskiej-emigracji-do-australii-poludniowej/.

79 P. Listkiewicz, Australia - przeklęta ziemia obiecana - wielokulturowość we wstecznym lusterku, http://studiozaprog1.blogspot.com/2011/05/piotr-listkiewicz-australia-przekleta_3863.html. 
pressed their political sympathy that way and chose to provide financial support for these undertakings ${ }^{80}$.

A vast majority of the emigrants from the second wave had either general secondary education or technical secondary education. Quite a few people representing that group also boasted post-leaving certificate education and higher education. It was believed that the degrees and skills mentioned would facilitate them in rapid success on the labour market. For the Australians, however, their education didn't mean much at all. Even then, the new country of the emigrants needed qualified workers, who would be able to fare well in a factory or at a construction site.

Moreover, there was no real demand for third level graduates or engineers, as this kind of people Australia already had ${ }^{81}$. This was especially noticeable when attempting to acknowledge degrees, where the main barrier proved to be a good command of the English language. As recounts Piotr Listkiewicz, "the main impediment constituted the English language examination, which was almost impossible to pass. Our Polish medicine doctor, who managed this after four years - for instance, she had to repeat her university education - used to say that medicine doctors born and educated in Australia said that probably even they would not be able to pass that exam. The scale of issue was elevated so high, so as to knock the emigrant professionals right at the very start down"82.

The language skills of the comers representing the second wave was not, however, a big problem. Based on the results of completed interviews with 60 emigrants of the second wave, Elizabeth Drozd stated that merely $8 \%$ of the research group frequently encountered problems with the understanding of English, and 16\% had some difficulties from time to time. The remaining $76 \%$ of people had no problems in understanding English language.

80 S. Markowski, K. Kwapisz Williams, Australian Polonia: A Diaspora on the Wane?, „Central and Eastern European Migration Review”, 2013, vol. 2, no. 1, p. 20.

81 P. Listkiewicz, Australia - przeklęta ziemia obiecana - wielokulturowość we wstecznym lusterku, http://studiozaprog1.blogspot.com/2011/05/piotr-listkiewicz-australia-przekleta_3863.html.

82 Ibid. 
For that matter, the skill of writing was a much greater challenge where $34 \%$ experienced difficulties either frequently or very frequently, whereas some $20 \%$ only at times. Over a half of the research group was very interested in improving the skill of writing in English. The problems with writing are still considerable for those who arrived in Australia over the last several dozen years, which also relates to those working as specialists in their fields ${ }^{83}$.

Despite the difficulties they have encountered, not all comers have managed to settle well in the new place, and for their decision to emigrate they have paid a price in marriage breakup, deterioration of their state of health, unemployment or lost contact with their families in Poland. One effect of "a long way, which they've gone" in connection with the perfecting of their command of the language, improvement of their professional status or satisfaction from their life and work was that many emigrants from the second wave managed to find their way in the new reality.

As Elizabeth Drozd writes, the achievement of all of this did not come easy. It was an effect of some hard work, further education, compromises, and using of skills and knowledge, which they've already encountered. They could also count on the support of the Australian multicultural policy. However, the most difficult challenge, in finding themselves in the new reality, apart from the language, was the experience of high level of isolation and stress, as well as longing for their families back in Poland. Their professional and educational fortunes were in a turmoil, "I didn't know English language, which I perceive as the biggest nightmare, a disaster for newcomer. Degree in economics, diploma of associate professor in technical operation I didn't throw to garbage bin, but hid deep into a drawer, and my dreams, ambitions, as well as professional plans, I put into my pocket, as I had to rapidly look for a new job, as in the first stage of my life it was the starting point in

83 E. Drozd, Managing an Ethnic Welfare Agency A Case Study of APCS from a Personal Perspective, In: Polonia in Australia: challenges and possibilities in the new millennium, eds. E. Drozd, D.A. Cahill, Victoria 2004, p. 46. 
sorting out my everyday things, life's problems and needs ${ }^{84 "}$. With the passing of time, many people regained their professional status, and right now are working in positions corresponding to their skills and qualifications ${ }^{85}$.

Piotr Listkiewicz confirms that "even though some good advice of the Polish diaspora, to get a job as domestic aid, factories and in construction, was accepted by our group with aversion and resistance, nevertheless almost all people from our emigration wave have gone through it. The difference was in that the former Polish diaspora stayed with that, and our group just treated it as a transitional period and as soon as cropped up an opportunity for changing job for a better one, did not hesitate to grab it" 86 . As Elizabeth Drozd recalls in her book: "I took up a job, which was offered to me. As an ordinary factory employee, I used to work on a production line, engaged in assembly of motor vehicle parts all day long, fixing something like four thousand screws onto dashboards" (...) "Knowing that this cannot go on for any longer, that I have no satisfaction of my life, I decided at all costs to raise my qualifications. What was needed most of all was to focus especially on the English language skills and with this in mind I got enrolled to Australian secondary school, which I used to attend three times a week after work." (...)

"One day, when I felt more self-assured, I went to personnel department at my work place, where I asked, what can I do to move from production hall to the office. I wanted to, stop working on production line, at any cost. At that time, I didn't manage to get anything worked out, but after a month's time, when a vacancy appeared, I was asked to the HR office and offered a job in the office in connection with ordering car parts, manufactured by our company. I felt relieved and my move

84 Z. Piotrowski, Ziemia obiecana, „Tygodnik Polski”, 30.10.1982, s. 5, to: M. Sprengel, Emigracja polska w Australii w latach 1980-2000, Toruń 2004, p. 69.

85 E. Drozd, Managing an Ethnic Welfare Agency A Case Study of APCS from a Personal Perspective, In: Polonia in Australia: challenges and possibilities in the new millennium, eds. E. Drozd, D.A. Cahill, Victoria 2004, p. 46.

86 P. Listkiewicz, Australia - przeklęta ziemia obiecana - wielokulturowość we wstecznym lusterku, http://studiozaprog1.blogspot.com/2011/05/piotr-listkiewicz-australia-przekleta_3863.html. 
to the office I treated as a big promotion. It was two and a half years after coming to Australia"87.

Many differences have existed between the first wave and the second one, which rarely favoured good mutual relations and co-operation between the two. Ewa Lipińska mentions that many "newcomers" have come to Australia as singles or as incomplete families, often settling quite far away from Polish diaspora centres, and avoiding contacts with fellow countrymen ${ }^{88}$. The second wave also frequently stayed back and did not join in the existing societies, but formed their own organisations, thus restraining themselves to activity within their own community and concentrating on the formation of the material foundations and professional career ${ }^{89}$. As Mieczysław Sprengel remarks, the first wave of emigrants felt complexes in contacts with the second one, as the "new" one was better educated, more self-assured and managed to fare well rapidly in the new conditions, and it was also characterised by the ability to take on risk ${ }^{90}$. For the first wave, contacting the second involved meeting "new Poland, post-war Poland of peasants promoted into intelligentsia in the first generation. The Poland of farmhands, slickers and petit salesmen. Poland of bums, who till nowadays boast not to have paid even a dollar of legal tax in Australia. Polish People's Republic, the whole spread. Similarly, to the post-war generation, they were faced here with degradation and struggle over many years to regain their social standing. Only that there were no counts in their ranks, so they accepted their fate easier"91.

Yet another element differentiating both sides were the conditions offered to the newcomers: staying at hostels, unemployment allowance for time of their education (training courses), and even accommoda-

87 E. Drozd, Dziewczyna z Korczyna, Toruń-Melbourne: 2017, p. 50-52.

88 E. Lipińska, Polskość w Australii: o dwujęzyczności, edukacji i problemach adaptacyjnych Polonii na antypodach, Kraków 2013, p. 60-61.

89 J. Lencznarowicz, Prasa i społeczność polska w Australii: 1928-1980, Kraków 1994, p. 31-32.

90 M. Sprengel, Emigracja polska w Australii w latach 1980-2000, Toruń 2004, p. 69.

91 Przemek, Krótka historia polskiej emigracji do Australii, http://antypody. info/2009/05/krotka-historia-polskiej-emigracji-do-australii/. 
tion. The first wave of emigrants had no such possibilities, as it had to work for two years away from larger urban areas, at times engaged in hardest of physical labour with not much chance for development ${ }^{92}$. Both waves came from "different Polands" and to "different Australias". During that time, both countries have changed and Australia, just like other countries, developed, economically, politically and culturally, thus generating for the newcomers much better living conditions than 30 years before ${ }^{93}$.

\section{Third wave}

The third wave of emigrants flew into Australia after 1989. Even though there is really very little difference in terms of time of arrival between the two waves, among others, they have differed in the place they came from. After 1989, the emigrants were already leaving a different Poland.

The reason for coming to Australia was also different. The political transformations in Poland meant that there was no need to flee the country; the economy was growing, the relics of socialist past were fading away and the borders could be crossed, if there were such a desire. What's characteristic is that also the third wave came to a different Australia than wave one and two; to a more modern country, more open to culture and education, but also more demanding of the newcomers.

The criteria for emigrants became more stringent, and thus the characteristic of the newcomers has changed in the process. These were and are young people, often well-educated or very well educated. Due to the fact that the argument of fleeing/refuge is gone, upon arriving, the emigrants needed to have financial resources allowing them to finance their stay until pinning down the right job and to pay for their education. Quite frequently, newcomers come from affluent families or possess qualifications, which enabled them to rapidly spot right job.

92 E. Lipińska, Polskość w Australii: o dwujęzyczności, edukacji i problemach adaptacyjnych Polonii na antypodach, Kraków 2013, p. 62-63.

93 M. Kowalczyk, Polska emigracja do Australii - kolejne fale aż po dzień dzisiejszy, 2014b, http://australink.pl/polska-emigracja-do-australii-kolejne-fale-azpo-dzien-dzisiejszy/. 
As writes Monika Krawczyk, "various Poles used to arrive, these somewhat on the young side making use of the student visa, willing to stay here for as long as possible and these somewhat older - thirty-fortyyear-old, who frequently want to move in here for good.

The situation of the Poles, who departed their country during that time period, was much less stressful, as they realised, that they can always come back to Poland, which was the thing that the earlier emigrants were not sure of"94. In the case of the young people, the main reasons for emigrating were their interest in enhancing their education, university study, getting trained or perfecting language skills, and hence attempts to settle in a new place, frequently linked to their curiosity of the world, open attitude towards new culture of new people. The older ones, for the most part, educated both in Poland and abroad, often with specialist education under their belts, opted for emigration most often for economic reasons and due to willingness to improve their living conditions (which were not all that bad anyhow) ${ }^{95}$.

Among the older emigrants there are also people who, before coming to Australia, had already experienced working and living abroad (e.g. in Great Britain and Ireland) ${ }^{96}$, as well as people, who are coming over here temporarily for definite time contracts (mainly engineers). Other reasons, if present, were just marginal. The number of emigrants of the third wave known as a "post-communist" wave of emigrants ${ }^{97}$ within a few years' time dropped from almost four thousand in mid90 s to approx. two thousand at the beginning of the $21^{\text {st }}$ century ${ }^{98}$, and to just several hundred a year at the present time.

94 M. Kowalczyk, Polska emigracja do Australii - kolejne fale aż po dzień dzisiejszy, 2014b, http://australink.pl/polska-emigracja-do-australii-kolejne-fale-azpo-dzien-dzisiejszy/.

95 Ibid.

96 D. Gromann, Polonia w Australii „Biuletyn Migracyjny” Dodatek Specjalny 2012, no. 33, p. 1.

97 E. Lipińska. Polscy imigranci początku lat dziewięćdziesiątych w Australii, In: Emigracja z Polski po 1989 roku, eds. B. Klimaszewski, Kraków 2002.

98 S. Markowski, Citizenship and integration: A snapshot of the Polish migrant community in Australia, „Humanities Research”, 2009, vol. XV, no. 1, p. 81. 
There are several reasons for such situation and the most important can be counted by the fact, that especially after the entrance of Poland to the EU, there are many places, often more attractive, which can be visited $^{99}$. The other reason is the distance between Poland and Australia, which means that visiting Poland several times a year is unacceptable for economic reasons, just like seasonal work ${ }^{100}$. Thus, decision and motives, as well as the conditions linked to arriving in Australia meant that people coming there had to be, and were in fact, better prepared for it than those belonging to the earlier waves ${ }^{101}$.

The Poles representing the third wave tried to improve their English language skills as fast as possible while staying in Australia (Australian to be more precise), while polishing the language they knew already and improving themselves professionally: "A part of them throughout the entire time makes a conscious effort not just to preserve their knowledge of Polish, but also develops and perfects it (not the language of the Polish diaspora), which lets them act for the wellbeing of the Polish diaspora, gain work as translators, journalists, etc. in prestigious institutions and assume higher positions in third level education, schools, institutions dealing with ethnical issues"102. As Jan Lencznarowicz remarks, the third wave seldom joins in the already existing Polish diaspora structures and rather tends to erect its own organisations; however, it is more focused on developing and improving its own living, material and professional situation ${ }^{103}$. A confirmation of this tendency can be found, among others, in the words of Przemek: "They did not accept that they were to start off from washing dishes at a fast food and very often they managed to get through to work in their own learnt

99 S. Markowski, K. Kwapisz Williams, Australian Polonia: A Diaspora on the Wane?, „Central and Eastern European Migration Review”, 2013, vol. 2, no. 1, p. 20.

100 J. Jupp, The Polish Impact on Australian Society, In: Polonia in Australia: challenges and possibilities in the new millennium, eds. E. Drozd, D.A. Cahill, Victoria 2004, p. 13.

101 E. Lipińska, Polskość w Australii: o dwujęzyczności, edukacji i problemach adaptacyjnych Polonii na antypodach, Kraków 2013, p. 62-63.

102 Ibid., p. 70.

103 J. Lencznarowicz, Prasa i społeczność polska w Australii: 1928-1980, Kraków 1994, p. 32. 
profession right away. They, too, are a cause of shock of the earlier generations of emigrants. They are an evidence of that Poland has healed its wounds, is alive, and perhaps better off than 50 or 100 years ago"104.

According to Janusz Wróbel's ${ }^{105}$, the third wave of emigration is characterised by its striving towards integration ${ }^{106}$, whereas separatist attitudes $^{107}$ and assimilative ones ${ }^{108}$ dominated in the earlier waves. However, all the groups are characterised by a marginalist attitude ${ }^{109},{ }^{110}$. The separatist attitude of emigrants was often traced to compulsory breaking down of relationships with their own country and the lack of possibility of returning or visiting Poland. This lack of "real" motherland translated into their focusing on mental motherland - "unreal one". Even though thousands of Poles have come to Australia for dozens of years, the community in Australia is very scanty in comparison with other countries. Add to that the clear lack of evidence for that its becoming bigger in a short spell of time ${ }^{111}$. On the basis of the population

104 Przemek, Krótka historia polskiej emigracji do Australii, http://antypody. info/2009/05/krotka-historia-polskiej-emigracji-do-australii/.

105 J. Wróbel, Podwójne życie Polonusa, czyli ontologia emigranta po 1989 roku (próba sformułowania hipotezy), In: Emigracja z Polski po 1989 roku, eds. B. Klimaszewski, Kraków 2002, p. 146.

106 Positive reception of „old” and „new” culture, an attempt to find / assimilate what is good in both. Pattern of operation I - Here + There - Now / Before.

107 Glorification of own culture and traditions, negation of the new one in which they found themselves. Functioning according to the pattern of Me-There-Before.

108 Low rate of self-culture assessment, strong need for assimilation. Marginalization of the influence of culture and ethnic traditions - the pattern of the functioning of I-Here-Now.

109 Negative rate of „old” and „new” culture. Drowning the past and turning away from the present. Functional formula (no)I'm-Not here/Not There - Not now/Not before.

110 J. Wróbel, Podwójne życie Polonusa, czyli ontologia emigranta po 1989 roku (próba sformułowania hipotezy), In: Emigracja z Polski po 1989 roku, eds. B. Klimaszewski, Kraków 2002, p 146.

111 A. Jamrozik, Social Welfare Services to the Polish Community Today and Tomorrow, In: Polonia in Australia: challenges and possibilities in the new millennium, eds. E. Drozd, D.A. Cahill, Victoria 2004, p. 37. 
Census $^{112}$, Polish origin declares 170354 people, while Poland as place of birth is confirmed by 48678 . Overall, some 22 million people live in Australia, of which one-quarter was born beyond Australia's borders.

Born in Poland, residents of Australia, data from the Australian censuses (CENSUS)

Table based on the results of the Australian census from 1921 to 2011.

http://www.abs.gov.au/websitedbs/censushome.nsf/home/historicaldata

\begin{tabular}{ccc}
\hline Date of the census & People born in Poland & $\begin{array}{c}+ \text { change compared to the } \\
\text { previous date of the census }\end{array}$ \\
\hline 1921 & 1780 & - \\
\hline 1933 & 3239 & 1459 \\
\hline 1947 & 6573 & 3334 \\
\hline 1954 & 56594 & 50021 \\
\hline 1961 & 60049 & 3455 \\
\hline 1966 & 61641 & 1592 \\
\hline 1971 & 59700 & -1941 \\
\hline 1976 & 56051 & -3649 \\
\hline 1981 & 59442 & 3391 \\
\hline 1986 & 67691 & 8249 \\
\hline 1991 & 68496 & 805 \\
\hline 1996 & 65113 & -3383 \\
\hline 2001 & 58110 & -7003 \\
\hline 2006 & 5256548 & -5854 \\
\hline
\end{tabular}

\section{Summary}

The historical-social-educational characteristic of the three waves of Polish emigration to Australia, indicates how much the circumstances in which individuals managed to find themselves are transposed into their

112 Department of Immigration and Border Protection, The People of Australia Statistics from the 2011 Census, 2014, https://www.homeaffairs.gov.au/ReportsandPublications/Documents/research/people-australia-2013-statistics.pdf. 
subsequent life choices. The first wave of settlers was forced to leave Poland. In realising that their way back to Poland was closed for many years to come, they have created for themselves a mock-up of Poland.

The new circumstances, in which they were to find themselves include their place of living, social roles and status, their separation from the indigenous population, their locations of places of living and work, and their earlier education and language skills. The upshot was that for many years, they have delayed their integration and did not favour their rapid social promotion. In consequence, all of this has led to social contact limited only to their own ethnic group and hence to the fading of any opportunities for subsequent educational development.

The overall outcome was that many of them remained at the same educational level as they had prior to their arrival. Just a small group of people have managed to get through and find themselves in a situation in which they could be further educated and develop professionally. It has only been the children of these emigrants who, unladen with the impediments their parents encountered on their way, have experienced greater freedom to function in Australia and so have managed to finish school and get better jobs.

The second wave, where the decision to emigrate to Australia was somewhat more voluntary, had completely different conditions of functioning in the new location. Here, aid was received from the Australian government in terms of accommodation, financial support, learning of language, all of which has facilitated them in making themselves at home in the new reality. The education that many of these emigrants received in Poland, and their language skills gained, have enabled them to take on more work more rapidly in positions they desire. Australia has more frequently accepted the emigrants' degrees and certificates, obtained back in Poland, which opened opportunities for their further development. This, in turn, has facilitated greater integration with Australians without departing from Polish values.

The decision to emigrate on the part of the third wave was completely voluntary. They have been in a position to fulfil the challenging requirements posed before emigrants - both professional and educational. Thus, in contrast to the preceding waves, the emigrants representing the third wave are not coming into the unknown, but fre- 
quently they need not start off from the scratch. They treat Australia as a category of adventure (inclusive of intellectual one) and not a necessity. Hence, it is hard to speak of a coincidence or else of an independent of them, circumstances being detrimental to their decision to arrive in this country. This is the thing favouring full voluntary integration with the place of destination (for the period of their stay).

All of these circumstances accompanying their changing place of stay have translated into decisions taken in a new location. They have also related to the decisions in connection with the model of functioning in new reality, as well as any of those in connection with social, cultural, family and professional goals. However, one thing remains unchanged. In spite of so many various circumstances in which they have found themselves, the Polish diaspora in Australia has been able to and still is able to preserve Polish values and culture, while at the same time being a valuable constituent part of Australian society.

\section{References}

Desmond, Cahill, "John Potaski, Australia's First Polish Settler A Problematic Beginning". In: Polonia in Australia: challenges and possibilities in the new millennium. ed. Elizabeth Drozd, Desmond Cahill, 1-8. Vic.: Common Ground Publishing, 2004.

Drozd, Elizabeth. They have come a long way: The settlement of the 1980s wave of Polish immigrants in Melbourne. Melbourne: Australian Polish Community Service. 2001.

Drozd, Elizabeth. "Managing an Ethnic Welfare Agency A Case Study of APCS from a Personal Perspective". In: Polonia in Australia: challenges and possibilities in the new millennium. ed. Elizabeth Drozd, Desmond Cahill, 1-8. Vic.: Common Ground Publishing, 2004.

Drozd, Elżbieta. Dziewczyna z Korczyna, Toruń-Melbourne: Oficyna Wydawnicza Kucharski, 2017.

Gromann, Daniel, "Polonia w Australii". Biuletyn Migracyjny dodatek Specjalny 33 (2012): 1-3. 
Harris, Roger, Smolicz, J. Jerzy. Australijczycy polskiego pochodzenia. Studium adaptacji i asymilacji młodego pokolenia. Wrocław: Zakład Narodowy im. Ossolińskich, Wydawnictwo Polskiej Akademii Nauk, 1984.

Department of Immigration and Border Protection. The People of Australia Statistics from the 2011 Census, 2014. https://www.homeaffairs.gov.au/ ReportsandPublications/Documents/research/people-australia-2013-statistics.pdf.

Jamrozik, Adam. "Recent Polish Immigration". In: The Australian People: An Encyclopedia of the Nation, it's People and their Origins, ed. James Jupp, Australia: Cambridge University Press, 2001.

Jamrozik, Adam. "Social Welfare Services to the Polish Community Today and Tomorrow". In: Polonia in Australia: challenges and possibilities in the new millennium. ed. Elizabeth Drozd, Desmond Cahill, 1-8. Vic.: Common Ground Publishing, 2004.

Jupp, James, "The Polish Impact on Australian Society". In: Polonia in Australia: challenges and possibilities in the new millennium. ed. Elizabeth Drozd, Desmond Cahill, 1-8. Vic.: Common Ground Publishing, 2004.

Knyżewski, Krzysztof. “O specyfice współczesnej polskiej emigracji”, In: Przemiany społeczne kwestie narodowościowe i polonijne. ed. Chodubski Andrzej, s. 75-81, Toruń: Wydawnictwo Adam Marszałek, 1994

Kowalczyk, Monika. Polska emigracja do Australii - początki i fala po II Wojnie Światowej, 2014. http://australink.pl/polska-emigracja-do-australiipoczatki-i-fala-po-ii-wojnie-swiatowej/.

Kowalczyk, Monika. Polska emigracja do Australii - kolejne fale aż po dzień dzisiejszy. 2014.http://australink.pl/polska-emigracja-do-australii-kolejnefale-az-po-dzien-dzisiejszy/.

Kunz, F. Egon. "Post-war non-British immigration". In: The Australian people: An encyclopedia of the nation, its people and their origins. ed. James Jupp, 100-106. Sydney: Angus \& Robertson, 1988.

Lencznarowicz, Jan. Prasa i społeczność polska w Australii: 1928-1980. Kraków: Księgarnia Akademicka, 1994.

Lencznarowicz, Jan. "Diaspora Polska w Australii". In: Polska Diaspora. ed. Adam Walaszek, 395-409. Kraków: Wydawnictwo Literackie, 2001.

Lipińska, Ewa. "Polscy imigranci początku lat dziewięćdziesiątych w Australii". In: Emigracja z Polski po 1989 roku. ed. Bolesław Klimaszewski, 443-457. Kraków: AN KBP Biblioteka Polonijna. Grell, 2002. 
Lipińska, Ewa. Polskość w Australii: o dwujęzyczności, edukacji i problemach adaptacyjnych Polonii na antypodach. Kraków: Wydawnictwo Uniwersytetu Jagiellońskiego, 2013.

Listkiewicz, Piotr. Australia - przeklęta ziemia obiecana - wielokulturowość we wstecznym lusterku. http://studiozaprog1.blogspot.com/2011/05/piotr-listkiewicz-australia-przekleta_3863.html

Markowski, Stefan. "Citizenship and integration: A snapshot of the Polish migrant community in Australia". Humanities Research 15(1), (2009): 75-99.

Markowski, Stefan. Kwapisz, W. Katarzyna. "Australian Polonia: A Diaspora on the Wane?". Central and Eastern European Migration Review 2(1). (2013): 13-36.

Paszkowski, Lech. Polacy w Australii i Oceanii 1790-1940. Toruń-Melborn: Towarzystwo Przyjaciół Archiwum Emigracji. Oficyna Wydawnicza Kucharski, 2008.

Price, A. Charles. "Jewish Settlers in Australia 1788-1961", Australian Jewish Historical Society Journal and Proceedings, 5(8) (1964): 357-412.

Przemek. Krótka historia polskiej emigracji do Australii, http://antypody. info/2009/05/krotka-historia-polskiej-emigracji-do-australii/.

Smolicz J. Jerzy. "Core values and cultural identity". Ethnic and Racial Studies 4(1), (1981): 75-90.

Smolicz J. Jerzy, Secombe, J. Margaret. Zostać Australijczykiem? Polski dom, australijska szkoła. Warszawa: Polonia, 1990.

Sprengel, Mieczysław. Emigracja polska w Australii w latach 1980-2000. Toruń: Wydawnictwo Adam Marszałek, 2004.

The New Polish Immigrants: A Quest for Normal Life. Sydney: Polish Task Force, 1983.

Thiele, Marysia. Trzy fale polskiej emigracji do Australii Południowej. http:// ewpl.com.au/trzy-fale-polskiej-emigracji-do-australii-poludniowej/

Włodarczak, Krystyna. "Proces adaptacji współczesnych emigrantów polskich do życia w Australii". CMR Working Papers 3/61(2005).

Wróbel, Janusz, "Podwójne życie Polonusa, czyli ontologia emigranta po 1989 roku (próba sformułowania hipotezy". In: Emigracja z Polski po 1989 roku. ed. Klimaszewski Bogdan, 137-150, Kraków: AN KBP Biblioteka Polonijna. Grell, 2002. 
